\title{
Karakteristik Yoghurt Probiotik dengan Penambahan Ekstrak Bunga Rosella (Hibiscus sabdariffa L) Selama Penyimpanan Suhu Dingin
}

\author{
Characteristics of Probiotic Yoghurt with Addition of Roselle Flower Extract (Hibiscus sabdariffa L) \\ During Cold Storage
}

\author{
R. T. Meilanie ${ }^{1}$, I. I. Arief $^{2}$, \& E. Taufik ${ }^{2}$ \\ ${ }^{1}$ Ilmu Produksi dan Teknologi Peternakan, Fakultas Peternakan, IPB \\ ${ }^{2}$ Departemen Ilmu Produksi dan Teknologi Peternakan, Fakultas Peternakan, IPB \\ Jl. Agatis Kampus IPB Dramaga, Bogor 16680 Indonesia \\ Email koresponden author: irma_isnafia@yahoo.com
}

\begin{abstract}
Yoghurt usually made by using two types of lactic acid bacteria (LAB) is Lactobacillus bulgaricus and Streptococcus thermophilus as starters, but the bacteria are not survive in very high acid condition. In order to develop probiotics yoghurt, the addition of lactic acid bacteria (LAB) with probiotic characteristics such as Lactobacillus acidophilus, Lactobacillus casei, and Bifidobacterium is needed. Roselle flower (Hibiscus sabdariffa $L$ ) is rich in antioxidants. The addition of roselle flower extract in yoghurt is expected to improve human health. This study aims to study the effect of cold storage (2$4^{\circ} \mathrm{C}$ ) on physical, chemical, microbiological and organoleptical characteristics of probiotic yoghurt with addition of roselle flower extract. Factorial randomized block design was used in this research. Tukey test was used as multiple range test. The results showed that there were significant interactions $(\mathbf{P}<\mathbf{0 . 0 5})$ between the types of yoghurt and time of storage to the $\mathrm{pH}$ value. The lowest $\mathrm{pH}$ value was yielded by the probiotic yoghurt with the addition of roselle flower extract. The different yoghurt types and storage time have significant effect on viscosity, total lactic acid bacteria (LAB), total titratable acidity, color and flavor.
\end{abstract}

Keywords: cold storage, probiotic, roselle flower, yoghurt

\section{PENDAHULUAN}

Yoghurt merupakan hasil olahan dari fermentasi susu atau susu rekonstitusi dengan menggunakan bakteri Lactobacillus delbrueckii subsp. bulgaricus (L. bulgaricus) dan Streptococcus salivarius subsp. thermophilus (S. thermophilus) atau bakteri asam laktat (BAL) lain yang sesuai, dengan atau tanpa penambahan bahan pangan lain dan bahan tambahan pangan yang diizinkan (Badan Standarisasi Nasional 2009). Menurut Astawan (2008), yoghurt mempunyai banyak manfaat bagi tubuh antara lain mengatur saluran pencernaan, antidiare, antikanker, meningkatkan pertumbuhan, membantu penderita lactose intolerance dan mengatur kadar kolesterol dalam darah.

Yoghurt umumnya dibuat dengan menggunakan dua jenis BAL yaitu L. bulgaricus dan S. thermophilus sebagai starter. Akan tetapi, kedua BAL yang digunakan dalam pembuatan yoghurt ini tidak bisa hidup dalam lingkungan yang keasamannya sangat tinggi. Jika bakteri tersebut mati saat mencapai usus kecil, maka keuntungan bakteri bagi kesehatan saluran pencernaan akan berkurang (Helferich dan Westhoff 1980). Yoghurt probiotik perlu dikembangkan, BAL yang bersifat probiotik, misalnya $L$. acidophilus, $L$. casei, dan Bifidobacterium yang dapat hidup dan melakukan metabolisme di dalam usus. Hal ini diperkuat oleh Surono (2004) yang menyatakan bahwa L. acidophilus merupakan bakteri asam laktat (BAL) yang resisten terhadap asam lambung dan masih dapat mempertahankan jumlah bakteri hidup sampai $10^{7}$ koloni $\mathrm{mL}^{-1}$. Selain itu, manfaat dari probiotik L. acidophilus IIA-2B4 terbukti dapat menghambat pertumbuhan bakteri patogen (Arief et al. 2015).

Rosella (Hibiscus sabdariffa L) merupakan salah satu tanaman berkhasiat. Kelopakbunga rosellaselainmempunyai rasa yang enak dan berkhasiat sebagai antioksidan juga dapat menghasilkan efek farmakologis yang cukup lengkap seperti antibakteri, antiseptik, antiradang, menurunkan panas, mencegah gangguan jantung, mencegah kanker darah, dan menstimulasi gerak peristaltik usus (Kustyawati dan Ramli 2008). Penambahan bunga rosella pada yoghurt juga memberikan rasa asam yang menyegarkan, aroma yang wangi serta berkhasiat karena bersifat sebagai antioksidan yang bermanfaat untuk meningkatkan kesehatan manusia saat dikonsumsi (Sihombing 2013).

Hasil analisis menunjukkan bahwa ekstrak bunga rosella memiliki pH sebesar 2.24 (Sihombing 2013). Tingkat keasaman yang tinggi dan keragaman antioksidan yang terkandung dalam ekstrak bunga rosella ini 
kemungkinan dapat mempengaruhi kinerja L. bulgaricus dan S. thermophilus selama masa penyimpanan. Pengaruh dari penambahan ekstrak bunga rosella perlu diminimalisir sehingga perlu adanya penambahan probiotik $L$. acidophilus yang lebih tahan pada lingkungan asam selama masa penyimpanan. Penelitian ini bertujuan mempelajari pengaruh lama waktu penyimpanan pada suhu dingin $\left(2-4^{\circ} \mathrm{C}\right)$ terhadap karakteristik fisik, kimia, mikrobiologi dan organoleptik yoghurt probiotik susu sapi dengan penambahan ekstrak bunga rosella (H. sabdariffa L) sebesar $1 \%$.

\section{MATERI DAN METODE}

\section{Waktu dan Lokasi Penelitian}

Penelitian dilaksanakan selama lima bulan, dimulai dari bulan Januari 2015 sampai Mei 2015. Penelitian dilaksanakan di Laboratorium Terpadu dan Ruang Uji Organoleptik, Departemen Ilmu Produksi dan Teknologi Peternakan, Fakultas Peternakan, Institut Pertanian Bogor, Bogor.

\section{Materi}

Susu sapi yang digunakan dalam penelitian ini diperoleh dari D-Farm, sementara bunga rosella ( $H$. sabdariffa L) kering diperoleh dari petani lokal. Kultur yoghurt yang digunakan antara lain L. achidophilus IIA-2B4, L. delbruecki subsp bulgaricus RRAM-01, Streptococcus salivarius subsp thermophilus RRAM-01 merupakan koleksi Laboratorium Teknologi Hasil Ternak, Departemen Ilmu Produksi dan Teknologi Peternakan, Fakultas Peternakan, Institut Pertanian Bogor. Media kultur yang digunakan antara lain deMann Rogosa Sharpe Broth (MRSB) (HIMEDIA, India), Buffer Pepton Water (BPW) (OXOID, Ltd Inggris) dan Agar Bacteriological (BA) (OXOID, Ltd Inggris).

\section{Prosedur}

Penelitian karakteristik fisik, kimia, mikrobiologi dan organoleptik yoghurt terdiri atas beberapa tahapan meliputi peremajaan starter, penyediaan kultur, pembuatan ekstrak bunga rosella, pembuatan yoghurt plain dan pembuatan yoghurt probiotik dengan penambahan ekstrak bunga rosella. Yoghurt disimpan pada suhu dingin $\left(2-4^{\circ} \mathrm{C}\right)$ dengan lama waktu penyimpanan yang berbeda, kemudian dilakukan beberapa pengujian.

\section{Peremajaan Starter}

Peremajaan starter dilakukan dengan cara menginokulasikan kultur yoghurt sebanyak $10 \%$ kedalam susu yang telah disterilisasi terlebih dahulu pada autoclave dengan suhu $115^{\circ} \mathrm{C}$ selama tiga menit. Selanjutnya diinkubasi pada suhu $37^{\circ} \mathrm{C}$ selama 18 jam sampai terbentuk koagulasi sehingga diperoleh kultur kerja.

\section{Penyediaan Kultur Yoghurt}

Penyediaan kultur yoghut dilakukan beradasarkan BAM (2001). Sebanyak 3\% dari kultur dalam susu ditambahkan pada media MRSA diinkubasi pada suhu $37^{\circ} \mathrm{C}$ selama 18 jam dan dihitung jumlah populasinya berdasarkan Bacteriological Analytical Manual (BAM) dengan rumus sebagai berikut :

$$
\mathrm{N}=\frac{\Sigma C}{[(1 \times n 1)+(0.1 \times n 2)} \mathrm{x} \mathrm{d}
$$

Keterangan :

$\mathrm{N} \quad$ : Jumlah koloni per $\mathrm{mL}$ atau per gram

$\Sigma \mathrm{C} \quad$ : Jumlah koloni dari tiap-tiap cawan petri (25-250 koloni cawan ${ }^{-1}$ )

n1 : Jumlah cawan dari pengenceran pertama yang koloninya dapat dihitung

n2 : Jumlah cawan dari pengenceran kedua yang koloninya dapat dihitung

d : Pengenceran pertama yang dihitung

\section{Pembuatan Ekstrak Bunga Rosella (Hibiscus sabdariffa} L)

Ekstraksi bunga rrosella dilakukan berdasarkan Tsai et al. (2001). Bunga rosella kering yang didapat dari petani digiling halus menjadi tepung, diayak dengan menggunakan ayakan 60 mesh. Tepung bunga rosella dilarutkan dalam air dengan perbandingan $20 \mathrm{~g}: 100 \mathrm{~mL}$ dan dipasteurisasi pada suhu $63-65{ }^{\circ} \mathrm{C}$ selama 30 menit. Kemudian disaring dan dievaporasi pada suhu $60^{\circ} \mathrm{C}$. Evaporasi dilakukan sampai didapatkan $10 \%$ ekstrak bunga rosella dari volume awal.

\section{Pembuatan Yoghurt Plain}

Pembuatan Yoghurt plain dilakukan berdasarkan Tamime dan Robinson (2007) dengan beberapa modifikasi. Kultur starter yoghurt L. bulgaricus dan S. thermophilus digunakan sebanyak 3\%. Yoghurt kemudian disimpan dalam suhu dingin $\left(2-4^{\circ} \mathrm{C}\right)$ dengan lama waktu penyimpanan yang berbeda. Diagram alir pembuatan yoghurt plain susu sapi disajikan dalam Gambar 1 .

\section{Pembuatan Yoghurt Probiotik dengan Penambahan Ekstrak Bunga Rosella (H. sabdariffa L)}

Proses pembuatan yoghurt probiotik dengan penambahan ekstrak bunga rosella dilakukan berdasarkan Sihombing (2013) dengan beberapa modifikasi. Kultur starter yoghurt dan probiotik seperti Lactobacillus bulgaricus, Streptococcus thermophilus, dan Lactobacillus achidophilus digunakan sebanyak 3\%. Ekstrak bunga rosella sebesar $1 \%$ ditambahkan pada yoghurt probiotik. Yoghurt disimpan dalam suhu dingin $\left(2-4^{\circ} \mathrm{C}\right)$ dengan lama waktu penyimpanan yang berbeda. Diagram alir pembuatan yoghurt probiotik dengan penambahan ekstrak bunga rosella disajikan dalam Gambar 2.

\section{Pengujian Karakteristik Yoghurt}

Karakteristik yoghurt yang diuji dalam penelitian ini meliputi karakteristik fisik, kimia, mikrobiologi dan organoleptik. Pengujian karakteristik fisik meliputi pengujian viskositas, nilai $\mathrm{pH}$, dan nilai $\mathrm{a}_{\mathrm{w}}$. Pengujian karakteristik kimia meliputi Total Asam Tertitrasi (TAT). Pengujian mikrobiologi mencakup total Bakteri Asam Laktat (BAL). Pengujian organoleptik yoghurt susu sapi dengan penambahan ekstrak bunga rosella meliputi uji hedonik.

\section{Pengujian Viskositas}

Pengukuran viskositas atau kekentalan yoghurt menggunakan alat viscotester merk Rion VT-04F (Jepang). Sampel sebanyak $150 \mathrm{~mL}$ dimasukkan pada gelas bejana lalu diuji dan dibaca nilai viskositasnya. 


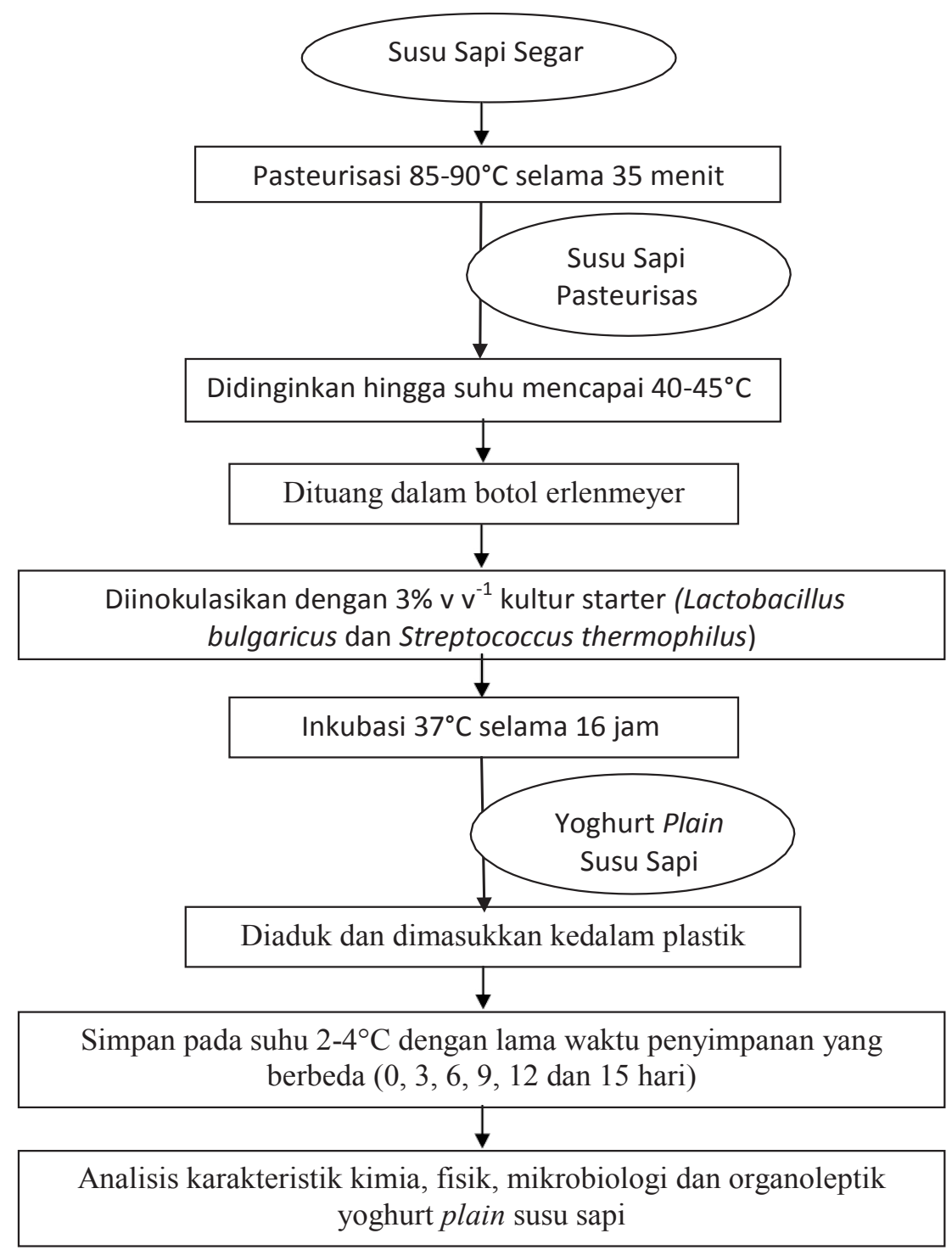

Gambar 1. Diagram alir pembuatan yoghurt plain

\section{Pengujian Nilai pH}

Pengukuran nilai $\mathrm{pH}$ dilakukan dengan $\mathrm{pH}$ meter merk Schoot Instrument (Jerman). Sebelumnya alat dikalibrasi menggunakan dua larutan buffer yang mewakili $\mathrm{pH}$ rendah $(4,00)$ dan $\mathrm{pH}$ tinggi $(7,00)$. Elektroda $\mathrm{pH}$ meter dicelupkan di dalam sampel, dan nilai $\mathrm{pH}$ dapat dibaca pada layar $\mathrm{pH}$ meter setelah menekan tombol call dan OK.

\section{Pengujian Aktivitas Air ( $\left.\mathbf{a}_{\mathrm{w}}\right)$}

Aktivitas air $\left(\mathrm{a}_{\mathrm{w}}\right)$ diukur menggunakan $\mathrm{a}_{\mathrm{w}}$ meter merk Novasina (Switzerland). Alat terlebih dahulu dikalibrasi dengan larutan $\mathrm{NaCl}$ jenuh sebelum digunakan. Larutan $\mathrm{NaCl}$ jenuh dimasukkan ke dalam chamber pengukuran, kemudian alat dinyalakan dengan menekan tombol start dan ditunggu sampai $\mathrm{a}_{\mathrm{w}}$ terbaca. Sampel dimasukkan ke dalam chamber, tombol start ditekan dan ditunggu hingga nilai $\mathrm{a}_{\mathrm{w}}$ terbaca.

\section{Pengujian Total Asam Tertitrasi (TAT)}

Pengukuran total asam tertitrasi diukur dengan menggunakan metode titrasi yang dinyatakan sebagai persentase (\%) asam laktat berdasarkan AOAC (2007).
Sampel sebanyak $10 \mathrm{~mL}$ ditambahkan indikator PP (fenolftalein) 1\% sebanyak 2-3 tetes $(300 \mu \mathrm{L})$ dan titrasi dilakukan dengan menambahkan $\mathrm{NaOH} 0.1 \mathrm{~N}$ hingga terjadi perubahan warna merah muda yang tetap. Total asam tertitrasi dihitung dengan menggunakan rumus sebagai berikut :

Total asam tertitrasi $(\%$ asam laktat $)=$

$$
\frac{a x b x 90,08}{1000 x c} \times 100 \%
$$

Keterangan :

a : volume $\mathrm{NaOH}$ yang digunakan $(\mathrm{mL})$

b : normalitas $\mathrm{NaOH}(\mathrm{N})$

c : volume sampel $(\mathrm{mL})$

\section{Total Bakteri Asam Laktat (BAL)}

Total BAL dihitung berdasarkan Pelczar dan Chan (2007). Sampel sebanyak $25 \mathrm{~mL}$ dimasukkan dalam tabung reaksi berisi $225 \mathrm{~mL}$ larutan BPW sehingga didapat pengenceran satu persepuluh $\left(\mathrm{P}^{-1}\right)$. Selanjutnya dari $\mathrm{P}^{-1}$ 


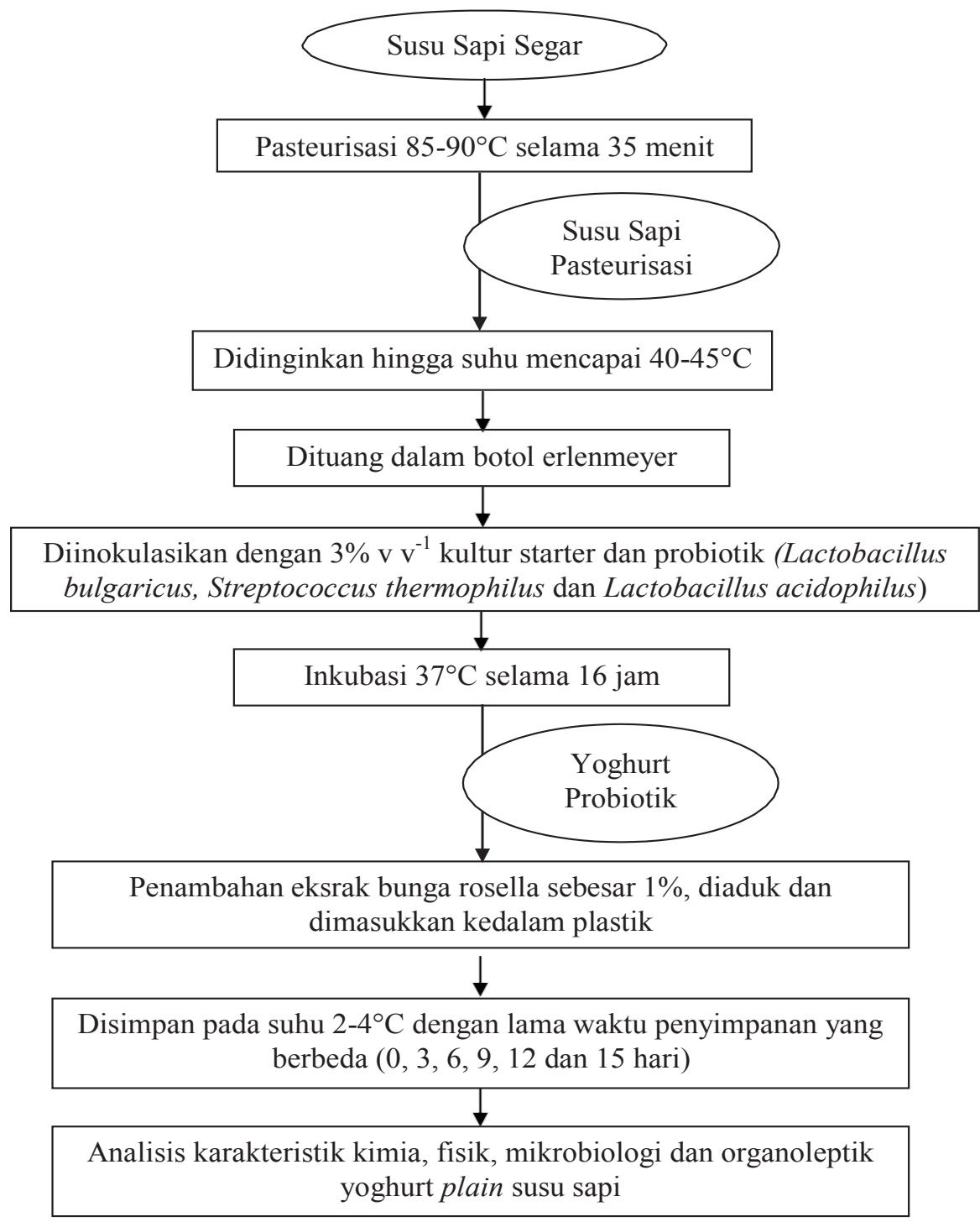

Gambar 2. Diagram alir pembuatan yoghurt probiotik dengan penambahan ekstrak bunga rosella

diambil sebanyak $1 \mathrm{~mL}$ dilarutkan ke dalam larutan pengencer BPW $9 \mathrm{ml}$ sehingga diperoleh $\mathrm{P}^{-2}$, demikian seterusnya dengan cara yang sama dilakukan sampai $\mathrm{P}^{-9}$. Pemupukan untuk bakteri asam laktat menggunakan metode tuang atau pour plate. Pemupukan dengan metode tuang dilakukan dengan cara mengambil sebanyak $1 \mathrm{~mL}$ sampel yang telah diencerkan kemudian disebarkan pada permukaan cawan Petri. Media MRSA steril sebanyak 12-15 mL dituangkan ke dalam cawan Petri dan dihomogenisasi agar sampel tersebar merata, lalu dibiarkan hingga media agar mengeras. Cawan Petri kemudian dibalik dan diinkubasi pada suhu $37^{\circ} \mathrm{C}$ selama $24-48$ jam. Jumlah bakteri asam laktat (BAL) ditentukan melalui penghitungan koloni BAL dalam cawan. Hasil analisis ditentukan berdasarkan Bacteriological Analytical Manual (BAM).

\section{Uji Organoleptik (Uji Hedonik)}

Uji organoleptik yang dilakukan adalah uji hedonik (tingkat kesukaan) berdasarkan Rahayu dan Nurosiyah (2008). Sampel disajikan di dalam cup plastik dengan ukuran yang seragam. Panelis terdiri dari 25 orang panelis tidak terlatih. Empat atribut yang dinilai pada uji organoleptik antara lain warna, aroma, kekentalan, dan rasa. Pada form uji organoleptik terdiri dari lima skala penilaian pada setiap atribut yang dinilai, yaitu (1) sangat tidak suka, (2) tidak suka, (3) agak suka, (4) suka dan (5) sangat suka.

\section{Rancangan dan analisis data}

Rancangan percobaan menggunakan Rancangan Acak Kelompok (RAK) pola faktorial 2 x 6 dengan 3 kali ulangan. Faktor pertama (A) adalah jenis yoghurt yang berbeda yaitu A1 = yoghurt probiotik susu sapi dengan penambahan ekstrak bunga rosella dan A2 = yoghurt plain susu sapi. Faktor kedua (B) adalah lama penyimpanan pada suhu dingin $\left(2-4^{\circ} \mathrm{C}\right)(\mathrm{B} 1=0$ hari, $\mathrm{B} 2=3$ hari, $\mathrm{B} 3=6$ hari, $\mathrm{B} 4=9$ hari, $\mathrm{B} 5=12$ hari dan $\mathrm{B} 6=15$ hari). Model rancangan percobaan menurut Steel dan Torrie (1995) adalah sebagai berikut:

Yijk $=\mu+K_{k}+A i+B j+(A B) i j+\epsilon i j k$

Keterangan :

Yijk : Nilai rata-rata hasil pengamatan pengaruh jenis yoghurt yang berbeda pada taraf ke-i (yoghurt 
probiotik susu sapi dengan penambahan ekstrak bunga rosella dan yoghurt susu sapi), lama penyimpanan pada taraf ke-j $(0,3,6,9,12$ dan 15 hari) danulangan ke-k (1, 2 dan 3)

$\mu \quad$ : nilai rataan umum

$\mathrm{K}_{\mathrm{k}} \quad$ : pengaruh kelompok ulangan ke-k (1, 2 dan 3)

$\mathrm{Ai} \quad$ : pengaruh jenis yoghurt yang berbeda pada taraf ke-i (yoghurt probiotik susu sapi dengan penambahan ekstrak bunga rosella dan yoghurt susu sapi)

Bj : pengaruh lama penyimpanan pada taraf ke-j $(0$, $3,6,9,12$ dan 15 hari)

(AB)ij : pengaruh interaksi antara penggunaan jenis yoghurt yang berbeda pada taraf ke-i (yoghurt probiotik susu sapi dengan penambahan ekstrak bunga rosella dan yoghurt susu sapi) dan lama penyimpan pada taraf ke-j $(0,3,6,9,12$ dan 15 hari)

Cijk : pengaruh galat percobaan dari jenis yoghurt yang berbeda pada taraf ke-i (yoghurt probiotik susu sapi dengan penambahan ekstrak bunga rosella dan yoghurt sususapi), lama penyimpan pada taraf ke-j $(0,3,6,9,12$ dan 15 hari) dan ulangan ke-k $(1,2$ dan 3$)$

Data dianalisis dengan analisis ragam (Analysis of Variance / ANOVA) untuk mengetahui pengaruh perlakuan terhadap peubah yang diamati. Jika perlakuan berbeda nyata terhadap peubah yang diukur maka dilanjutkan dengan uji Tukey. Data non parametrik diuji dengan uji Kruskal Wallis.

\section{HASIL DAN PEMBAHASAN}

\section{Viskositas}

\section{Karakteristik Fisik Yoghurt Probiotik}

Viskositas atau kekentalan adalah suatu hambatan yang menahan zat cair secara molekuler yang disebabkan oleh gerakan acak molekul zat cair tersebut (Susanto dan Yuwono 2001). Hasil pengukuran viskositas yoghurt selama penyimpanan suhu dingin disajikan pada Tabel 1. Hasil analisis ragam menunjukkan bahwa jenis yoghurt dan lama penyimpanan berpengaruh nyata $(\mathrm{P}<0,05)$ terhadap nilai viskositas yoghurt, namun tidak saling berinteraksi
( $P>0,05)$. Viskositas dari kedua jenis yoghurt yang terukur selama penyimpanan berkisar antara 1,27-3,07 dPa. Rataan nilai viskositas dari hari ke-0 sampai ke-15 mengalami peningkatan pada kedua jenis yoghurt. Peningkatan viskositas disebabkan karena peningkatan jumlah eksopolisakarida. Eksopolisakarida adalah polisakarida yang dihasilkan oleh BAL pada kondisi lingkungan hidup yang ekstrim (Nudyanto dan Zubaidah 2014). Menurut Ruas et al. (2002), eksopolisakarida diproduksi oleh berbagai macam bakteri asam laktat yaitu Lactobacillus, Streptococcus, Lactococcus, dan Leuconostoc.

Viskositas yoghurt juga dipengaruhi oleh nilai $\mathrm{pH}$. Yoghurt probiotik dengan penambahan ekstrak bunga rosella memiliki nilai $\mathrm{pH}$ yang lebih rendah dibandingkan nilai $\mathrm{pH}$ yoghurt plain. Berdasarkan nilai $\mathrm{pH}$ yang didapatkan, nilai $\mathrm{pH}$ yoghurt plain berada pada kisaran titik isoelektris ( $\mathrm{pH} 4,6-4,7)$ yang merupakan awal terjadinya koagulasi. Yoghurt plain menghasilkan viskositas lebih rendah dibandingkan dengan yoghurt probiotik, dimana nilai $\mathrm{pH}$ yoghurt probiotik sudah melewati titik isoelektris ( $\mathrm{pH} 4,6-4,7$ ) sehingga koagulan yang terbentuk akan lebih kental. Hal ini sesuai dengan pernyataan Daulay (1991) protein susu (kasein) menggumpal pada titik isoelektris $\mathrm{pH}$ 4,7. Ditambahkan oleh Djaafar dan Rahayu (2006) bahwa $\mathrm{pH}$ 4,4-4,5 akan tercapai titik isoelektris protein sehingga terjadi penggumpalan, yaitu suatu perubahan bentuk susu dari cair menjadi padatan.

\section{Aktivitas Air $\left(\mathbf{a}_{\mathbf{w}}\right)$}

Aktivitas air atau $\mathrm{a}_{\mathrm{w}}$ adalah jumlah air bebas yang dapat digunakan oleh mikroba untuk pertumbuhannya. Air bebas pada bahan pangan dibutuhkan untuk pertumbuhan mikroba, terutama untuk proses transpor nutrisi, media untuk reaksi enzimatik, sintesis komponen seluler, dan berperan dalam reaksi biokimia (Rahayu dan Nurwitri 2012). Hasil $a_{w}$ pada jenis yoghurt yang berbeda selama masa penyimpanan dapat dilihat pada Tabel 2.

Hasil analisis ragam menunjukkan bahwa perlakuan jenis yoghurt tidak berpengaruh nyata $(\mathrm{P}>0,05)$ terhadap aktivitas air $\left(\mathrm{a}_{\mathrm{w}}\right)$, sedangkan lama penyimpanan berpengaruh nyata $(\mathrm{P}<0,05)$ terhadap aktivitas air $\left(\mathrm{a}_{\mathrm{w}}\right)$. Aktivitas air berpengaruh terhadap kualitas dari suatu bahan karena akan memungkinkan terjadinya pertumbuhan mikroba (Winarno et al. 1980). Nilai $\mathrm{a}_{\mathrm{w}}$ dari kedua jenis yoghurt selama

Tabel 1. Viskositas ( $\mathrm{dPa}$ ) yoghurt selama penyimpanan suhu dingin

\begin{tabular}{|c|c|c|c|}
\hline \multirow[t]{2}{*}{ Lama penyimpanan hari ke- } & \multicolumn{2}{|c|}{ Jenis Yoghurt } & \multirow[t]{2}{*}{ Rataar } \\
\hline & YPR & $\mathrm{Y}$ & \\
\hline 0 & $1,90 \pm 0,35$ & $1,27 \pm 0,55$ & $1,58 \pm 0,54 d$ \\
\hline 3 & $2,20 \pm 0,50$ & $1,70 \pm 0,53$ & $1,95 \pm 0,54 \mathrm{~cd}$ \\
\hline 6 & $2,33 \pm 0,50$ & $1,90 \pm 0,62$ & $2,12 \pm 0,56 b c$ \\
\hline 9 & $2,57 \pm 0,42$ & $2,07 \pm 0,57$ & $2,32 \pm 0,52 b c$ \\
\hline 12 & $2,77 \pm 0,42$ & $2,27 \pm 0,57$ & $2,52 \pm 0,52 \mathrm{ab}$ \\
\hline 15 & $3,07 \pm 0,45$ & $2,53 \pm 0,67$ & $2,80 \pm 0,59 a$ \\
\hline Rataan & $2,47 \pm 0,54 a$ & $1,96 \pm 0,65 b$ & \\
\hline
\end{tabular}

Keterangan: Huruf pada kolom atau baris yang sama menunjukkan berbeda nyata $(\mathrm{P}<0,05)$. YPR : Yoghurt probiotik + rosella, Y : Yoghurt plain. 
Meilanie et al.

Jurnal Ilmu Produksi dan Teknologi Hasil Peternakan 6 (1): 36-44

Tabel 2. Nilai aw yoghurt selama penyimpanan suhu dingin

\begin{tabular}{lccc}
\hline Lama penyimpanan hari ke- & \multicolumn{2}{c}{ Jenis Yoghurt } & Rataan \\
\cline { 2 - 3 } & YPR & Y & \\
\hline 0 & $0,86 \pm 0,01$ & $0,86 \pm 0,00$ & $0,857 \pm 0,007 \mathrm{ab}$ \\
3 & $0,86 \pm 0,01$ & $0,86 \pm 0,01$ & $0,863 \pm 0,010 \mathrm{a}$ \\
6 & $0,85 \pm 0,01$ & $0,86 \pm 0,00$ & $0,857 \pm 0,008 \mathrm{ab}$ \\
9 & $0,87 \pm 0,00$ & $0,86 \pm 0,01$ & $0,863 \pm 0,005 \mathrm{a}$ \\
12 & $0,85 \pm 0,00$ & $0,85 \pm 0,02$ & $0,850 \pm 0,011 \mathrm{~b}$ \\
15 & $0,86 \pm 0,01$ & $0,85 \pm 0,01$ & $0,851 \pm 0,010 \mathrm{~b}$ \\
\hline Rataan & $0,86 \pm 0,01$ & $0,86 \pm 0,01$ & \\
\hline
\end{tabular}

Keterangan: Huruf pada kolom atau baris yang sama menunjukkan berbeda nyata $(\mathrm{P}<0,05)$. YPR : Yoghurt probiotik + rosella, Y : Yoghurt plain.

penyimpanan berada diantara $0,85-0,87$. Pertumbuhan jasad renik yang mungkin terjadi pada yoghurt menurut Syarief dan Halid (1993) adalah kapang. Peningkatan nilai $\mathrm{a}_{\mathrm{w}}$ terjadi pada hari ke-3 dan ke-9, selanjutnya nilai $\mathrm{a}_{\mathrm{w}}$ mengalami penurunan sampai hari ke-15. Hal ini menunjukkan bahwa mikroba mulai tumbuh kembali setelah hari ke-3 dan k-9. Peningkatan $a_{w}$ selama penyimpanan disebabkan oleh degradasi molekul-molekul pada bahan oleh mikroorganisme berupa pelepasan air terikat yang mengakibatkan terbentuknya air bebas. Penurunan $\mathrm{a}_{\mathrm{w}}$ mengindikasikan kondisi yang sesuai untuk menghambat pertumbuhan jasad renik pada pangan.

\section{Nilai pH}

Karakteristik Kimia Yoghurt Probiotik

Nilai $\mathrm{pH}$ merupakan salah satu karakteristik penting dalam penilaian produk susu seperti yoghurt. Nilai $\mathrm{pH}$ suatu cairan berhubungan dengan konsentrasi ion hidrogen $\left(\mathrm{H}^{+}\right)$ di dalamnya. BAL pada umumnya menghasilkan sejumlah besar asam laktat dari fermentasi substrat energi karbohidrat (Sitasi?). Hasil pengukuran nilai $\mathrm{pH}$ yoghurt selama penyimpanan suhu dingin disajikan pada Tabel 3 .

Hasil analisis ragam menunjukkan bahwa jenis yoghurt dan lama penyimpanan serta interaksi antara keduanya berpengaruh nyata $(\mathrm{P}<0,05)$ terhadap nilai $\mathrm{pH}$ yoghurt. Rendahnya nilai $\mathrm{pH}$ secara umum berhubungan dengan asam organik yang diproduksi oleh bakteri asam laktat. Menurut Oberman (1985) menyatakan bahwa kisaran $\mathrm{pH}$ susu fermentasi yaitu 3,80-4,60, bahkan Jay (2000) memberikan kisaran pH yoghurt yang lebih lebar

Tabel 3. Nilai $\mathrm{pH}$ yoghurt selama penyimpanan suhu dingin

\begin{tabular}{|c|c|c|}
\hline \multirow{2}{*}{$\begin{array}{l}\text { Lama penyimpanan } \\
\text { hari ke- }\end{array}$} & \multicolumn{2}{|c|}{ Jenis Yoghurt } \\
\hline & YPR & $\mathrm{Y}$ \\
\hline 0 & $3,73 \pm 0,03 c$ & $4,64 \pm 0,07 a$ \\
\hline 3 & $3,71 \pm 0,09 \mathrm{c}$ & $4,46 \pm 0,10 \mathrm{ab}$ \\
\hline 6 & $3,73 \pm 0,05 c$ & $4,39 \pm 0,12 \mathrm{ab}$ \\
\hline 9 & $3,71 \pm 0,08 \mathrm{c}$ & $4,32 \pm 0,15 \mathrm{ab}$ \\
\hline 12 & $3,74 \pm 0,07 \mathrm{c}$ & $4,29 \pm 0,16 b$ \\
\hline 15 & $3,69 \pm 0,04 c$ & $4,17 \pm 0,21 b$ \\
\hline
\end{tabular}

Keterangan: Huruf pada kolom atau baris yang sama menunjukkan berbeda nyata $(\mathrm{P}<0,05)$. YPR : Yoghurt probiotik + rosella, Y : Yoghurt plain. lagi yaitu antara 3,65-4,40. Nilai pH yoghurt probiotik dengan penambahan ekstrak bunga rosella maupun yoghurt plain masih dalam kisaran standar. Rendahnya nilai $\mathrm{pH}$ pada yoghurt probiotik dengan penambahan ekstrak bunga rosella disebabkan oleh kandungan asam yang terdapat pada ekstrak bunga rosella yang memiliki $\mathrm{pH}$ sebesar 2,24 (Sihombing 2013).

Penurunan nilai $\mathrm{pH}$ selama penyimpanan disebabkan oleh adanya aktivitas BAL yang merubah laktosa menjadi asam laktat. Asam laktat yang dihasilkan dari metabolisme karbohidrat dapat menurunkan nilai $\mathrm{pH}$ lingkungan pertumbuhannya dan menimbulkan rasa asam (Winarno dan Fernandez 2007). Penambahan ekstrak bunga rosella pada yoghurt probiotik menunjukkan nilai $\mathrm{pH}$ yang relatif konstan dari hari ke-0 sampai hari ke-15 penyimpanan, hal ini diduga terjadi karena adanya penambahan ekstrak bunga rosella yang memiliki $\mathrm{pH}$ rendah sehingga mempengaruhi kinerja dari bakteri asam laktat (BAL). Menurut Jay (2000), L. bulgaricus tumbuh sangat baik pada $\mathrm{pH}$ optimum 5,5 dan pertumbuhannya dapat terhenti pada $\mathrm{pH} 3,5-3,8$, sedangkan S. thermophilus akan terhenti pada $\mathrm{pH} 4,2-4,4$.

\section{Total Asam Tertitrasi (TAT)}

Besarnya nilai total asam tertitrasi (TAT) berbanding terbalik dengan nilai $\mathrm{pH}$. Nilai TAT menunjukkan jumlah semua asam yang terdapat dalam yoghurt, baik asam yang terdisosiasi maupun asam yang tidak terdisosiasi (sitasi ?). Hasil total asam tertitrasi (TAT) yoghurt disajikan pada Tabel 4.

Hasil analisis ragam menunjukkan bahwa hanya jenis yoghurt yang berpengaruh nyata $(\mathrm{P}<0,05)$ terhadap nilai TAT yoghurt. Nilai TAT pada kedua jenis yoghurt selama masa penyimpanan masih memenuhi nilai standar SNI Mutu Yoghurt (Badan Standarisasi Nasional 2009) yaitu $0,5 \%-2,0 \%$. Nilai TAT yang tinggi pada yoghurt probiotik rosella menunjukkan tingginya persentase asam terdisosiasi maupun tidak terdisosiasi yang dihasilkan oleh aktivitas kultur starter bakteri asam laktat dan ekstrak bunga rosella. Nilai total asam tertitrasi pada yoghurt yang dihasilkan berbanding terbalik dengan nilai $\mathrm{pH}$. Hal ini disebabkan semakin tinggi jumlah asam yang dihasilkan, maka penurunan $\mathrm{pH}$ akan semakin tinggi.

\section{Karakteristik Mikrobiologi Yoghurt}

Uji mikrobiologi yoghurt dilakukan untuk mengetahui jumlah BAL yang terdapat dalam yoghurt. 
Meilanie et al.

Jurnal Ilmu Produksi dan Teknologi Hasil Peternakan 6 (1): 36-44

Tabel 4. Nilai TAT (\%) yoghurt selama penyimpanan suhu dingin

\begin{tabular}{lccc}
\hline Lama penyimpanan hari ke- & \multicolumn{2}{c}{ Jenis Yoghurt } & Rataan \\
\cline { 2 - 3 } & YPR & Y & \\
\hline 0 & $1,59 \pm 0,13$ & $0,81 \pm 0,12$ & $1,20 \pm 0,44$ \\
3 & $1,58 \pm 0,15$ & $0,87 \pm 0,10$ & $1,23 \pm 0,41$ \\
6 & $1,60 \pm 0,13$ & $0,90 \pm 0,10$ & $1,25 \pm 0,39$ \\
9 & $1,59 \pm 0,13$ & $0,91 \pm 0,10$ & $1,25 \pm 0,38$ \\
12 & $1,59 \pm 0,13$ & $0,92 \pm 0,09$ & $1,25 \pm 0,38$ \\
15 & $1,58 \pm 0,14$ & $1,11 \pm 0,32$ & $1,35 \pm 0,34$ \\
\hline Rataan & $1,59 \pm 0,12 \mathrm{a}$ & $0,92 \pm 0,17 \mathrm{~b}$ & \\
\hline Keterangan & &
\end{tabular}

Keterangan: Huruf pada kolom atau baris yang sama menunjukkan berbeda nyata $(\mathrm{P}<0,05)$. YPR : Yoghurt probiotik + rosella, Y : Yoghurt plain.

Tabel 5. Total BAL ( $\log 10 \mathrm{cfu} \mathrm{mL}-1)$ yoghurt selama penyimpanan suhu dingin

\begin{tabular}{lccc}
\hline Lama penyimpanan hari ke- & \multicolumn{2}{c}{ Jenis Yoghurt } & Rataan \\
\cline { 2 - 3 } & YPR & Y & \\
\hline 0 & $9,07 \pm 0,22$ & $9,73 \pm 0,39$ & $9,40 \pm 0,46 \mathrm{a}$ \\
3 & $9,01 \pm 0,19$ & $9,66 \pm 0,40$ & $9,33 \pm 0,45 \mathrm{ab}$ \\
6 & $8,77 \pm 0,19$ & $9,63 \pm 0,40$ & $9,20 \pm 0,55 \mathrm{ab}$ \\
9 & $8,55 \pm 0,07$ & $9,32 \pm 0,01$ & $8,93 \pm 0,42 \mathrm{bc}$ \\
12 & $8,22 \pm 0,25$ & $9,29 \pm 0,04$ & $8,75 \pm 0,61 \mathrm{c}$ \\
15 & $8,02 \pm 0,20$ & $9,00 \pm 0,38$ & $8,51 \pm 0,60 \mathrm{c}$ \\
\hline Rataan & $8,61 \pm 0,43 \mathrm{~b}$ & $9,44 \pm 0,38 \mathrm{a}$ & \\
\hline Keteranan
\end{tabular}

Keterangan: Huruf pada kolom atau baris yang sama menunjukkan berbeda nyata $(\mathrm{P}<0,05)$. YPR : Yoghurt probiotik + rosella, Y : Yoghurt plain.

Bakteri asam laktat (BAL) adalah kelompok bakteri yang mampu mengubah karbohidrat (glukosa) menjadi asam laktat. Hasil analisis ragam pada Tabel 5 menunjukkan bahwa jenis yoghurt berpengaruh nyata $(\mathrm{P}<0,05)$ terhadap total bakteri asam laktat (BAL). Total bakteri asam laktat (BAL) pada yoghurt probiotik dengan penambahan ekstrak bunga rosella lebih rendah dibandingkan dengan yoghurt plain disebabkan oleh adanya kandungan senyawa fenol, flavonoid, tannin dan saponin pada ekstrak bunga rosella yang salah satu diantaranya diduga sebagai komponen antibakteri (Rostinawati 2009). Lama penyimpanan memberikan pengaruh yang nyata $(\mathrm{P}<0,05)$ terhadap total bakteri asam laktat yoghurt, dimana semakin lama penyimpanan total bakteri asam laktat juga semakin menurun. Penurunan total bakteri asam laktat selama masa penyimpanan disebabkan bakteri memasuki fase pertumbuhan stationer. Menurut Legowo et al. (2009) fase pertumbuhan stationer terjadi karena sebagian mikroba sudah tumbuh tetapi sebagian lainnya sudah mati. Penurunan populasi BAL pada kedua jenis yoghurt selama masa penyimpanan masih memenuhi nilai SNI 01-2981-2009 Mutu Yoghurt (Badan Standarisasi Nasional 2009) yaitu minimal sebesar $10^{7} \mathrm{cfu} \mathrm{mL}^{-1}$. Jumlah probiotik yang dipersyaratkan oleh Swiss Food Regulation and International standar adalah $>10^{6} \mathrm{cfu} \mathrm{g}^{-1}$ (Jay et al. 2005).

\section{Karakteristik Organoleptik Yoghurt}

Uji organoleptik yang dilakukan adalah uji hedonik. Uji hedonik dilakukan untuk mengetahui tingkat kesukaan panelis terhadap yoghurt yang dihasilkan. Atribut yang dinilai meliputi aroma, warna, rasa dan kekentalan. Nilai rataan hasil uji hedonik yoghurt disajikan pada Tabel 6. Hasil analisis dengan menggunakan uji Kruskal Wallis terhadap beberapa atribut sensori menunjukkan bahwa jenis yoghurt dan lama penyimpanan berpengaruh nyata $(\mathrm{P}<0,05)$ terhadap warna dan rasa berdasarkan penilaian panelis. Warna yang dihasilkan dari jenis yoghurt dengan penambahan ekstrak bunga rosella memiliki tingkat kesukaan yang lebih rendah dibandingkan dengan yoghurt plain. Hal ini menunjukkan bahwa warna yoghurt plain lebih disukai.

Pengaruh penambahan ekstrak bunga rosella memberikan warna merah muda pada yoghurt probiotik. Menurut Kustyawati dan Ramli (2008), pigmen alami yang memberi warna merah pada bunga rosella adalah antosianin. Antosianin memiliki sifat antioksidan yang kuat. Antosianin sangat stabil pada $\mathrm{pH}$ rendah (2-4) dan berwarna merah, pada $\mathrm{pH}$ 4-6 antosianin berwarna ungu, pada $\mathrm{pH}$ 7-8 berwarna biru, dan kemudian berwarna kuning pada $\mathrm{pH}>8$ (Brannen et al. 2002).

Tingkat kesukaan rasa yoghurt probiotik dengan penambahan ekstrak bunga rosella pada lama penyimpanan hari ke-3 lebih disukai dibandingkan dengan yoghurt plain, sedangkan pada lama penyimpanan hari ke-0 dan ke-6 panelis lebih menyukai rasa yoghurt plain. Penambahan bunga rosella pada yoghurt memberikan rasa asam yang menyegarkan, aroma yang wangi serta berkhasiat karena bersifat sebagai antioksidan yang bermanfaat untuk meningkatkan kesehatan manusia saat dikonsumsi (Sihombing 2013). 
Tabel 6. Nilai rataan uji hedonik yoghurt selama penyimpanan suhu dingin

\begin{tabular}{llrrr}
\hline Atribut & Jenis yoghurt & \multicolumn{3}{l}{ Lama penyimpanan hari ke- } \\
\cline { 3 - 5 } & & 0 & 3 & 6 \\
\hline Aroma & YPR & $2,80 \pm 0,82$ & $3,32 \pm 0,90$ & $3,08 \pm 0,86$ \\
& Y & $3,20 \pm 1,00$ & $3,08 \pm 0,91$ & $3,16 \pm 0,99$ \\
\hline \multirow{2}{*}{ Warna } & YPR & $2,68 \pm 0,90 \mathrm{~b}$ & $3,00 \pm 0,82 \mathrm{ab}$ & $3,12 \pm 1,01 \mathrm{ab}$ \\
& Y & $3,60 \pm 0,71 \mathrm{a}$ & $3,56 \pm 0,71 \mathrm{a}$ & $3,56 \pm 0,82 \mathrm{a}$ \\
\hline Rasa & YPR & $2,72 \pm 0,89 \mathrm{ab}$ & $3,60 \pm 0,91 \mathrm{a}$ & $2,52 \pm 0,82 \mathrm{~b}$ \\
& Y & $3,48 \pm 0,96 \mathrm{a}$ & $3,32 \pm 0,99 \mathrm{ab}$ & $3,48 \pm 1,00 \mathrm{a}$ \\
\hline Kekentalan & YPR & $2,76 \pm 0,78$ & $3,20 \pm 0,82$ & $3,08 \pm 0,81$ \\
& Y & $2,88 \pm 0,83$ & $3,00 \pm 0,76$ & $2,76 \pm 0,88$ \\
\hline
\end{tabular}

Keterangan: Huruf pada kolom atau baris yang sama menunjukkan berbeda nyata $(\mathrm{P}<0,05)$. YPR : Yoghurt probiotik + rosella, Y : Yoghurt plain. 1: sangat tidak suka; 2: tidak suka; 3: agak suka; 4: suka; 5: sangat suka

\section{KESIMPULAN}

Hasil penelitian menunjukkan bahwa jenis yoghurt dan lama waktu penyimpanan berpengaruh nyata $(\mathrm{P}<0,05)$ terhadap nilai $\mathrm{pH}$ produk. Nilai $\mathrm{pH}$ yang terendah dihasilkan dari yoghurt probiotik dengan penambahan ekstrak bunga rosella. Jenis yoghurt dan lama penyimpanan yang berbeda berpengaruh nyata $(\mathrm{P}<0,05)$ terhadap viskositas, total bakteri asam laktat (BAL) dan total asam tertitrasi (TAT). Jenis yoghurt dan lama penyimpanan berpengaruh nyata $(\mathrm{P}<0,05)$ terhadap warna dan rasa berdasarkan penilaian panelis pada uji organoleptik. Yoghurt probiotik dengan penambahan ekstrak bunga rosella selama masa penyimpanan masih sesuai dengan Standar Nasional Indonesia Mutu Yoghurt 01-2981-2009 dan Swiss Food Regulation and International standar sebagai pangan probiotik.

\section{DAFTAR PUSTAKA}

[AOAC] Association of Official Analytical Chemistry. 2007. Official Methods of Analysis. Washington DC (US): Association of Analytical Chemistry.

[BSN] Badan Standardisasi Nasional. 2009. SNI. 012981-2009: Yoghurt. Jakarta (ID): Badan Standardisasi Nasional.

Arief II, Betty SLJ, Made A, Kazuhito F, Arief BW. 2015. Identification and probiotics characteristics of lactic acid bacteria isolated from Indonesian local beef. Asian Journal of Animal Science 9 (1): 25-36.

Brannen LA, Davidson PM. 1993. Antimicrobials in Foods. New York (US): Marcel Dekker.

Daulay D. 1991. Fermentasi Keju. Bogor (ID): Departemen Pendidikan dan Kebudayaan. Dirjen Dikti dan Pau Pangan dan Gizi Institut Pertanian Bogor.

Djaafar TF, Rahayu ES. 2006. Karakteristik yogurt dengan inokulum Lactobacillus yang diisolasi dari makanan fermentasi tradisional. Jurnal Agros. 8(1): 73-80.

Helferich W, Westhoff DC. 1980. All About Yoghurt. New York (US): Prentice Hall.

Jay JM, Loessner MJ, Golden DA. 2005. Modern Food Microbyology. Ed ke-7. USA (US): Springer.

Jay JM. 2000. Modern Food Microbiology. 6th ed.
Maryland (US): Aspen Publisher.

Kustyawati ME, Ramli S. 2008. Pemanfaatan hasil tanaman hias rosella sebagai bahan minuman. Prosiding Seminar Nasional Sains dan Teknologi-II; (VIII): 127-135, 17-18 Nov 2008. Jurusan Teknologi Hasil Pertanian. Fakultas Pertanian.Lampung (ID): Universitas Lampung.

Legowo AM, Kusrahayu, Mulyani S. 2009. Ilmu dan Teknologi Susu. Semarang (ID): UNDIP Pr.

Nudyanto A, Zubaidah E. 2014. Isolasi bakteri asam laktat penghasil eksopolisakarida dari kimchi. Jurnal Pangan Dan Agroindustri. 3 (2) : 743-748.

Oberman H. 1985. Fermented Milk. Di dalam Wood BJB. (ed). Microbiology of Fermented Food. Vol 1. New York (US): Elsevier Applied Science.

Pelczar MJ, Chan ECS. 2007. Dasar-dasar mikrobiologi Jilid I. Terjemahan Hadioetomo RS, Imas T, Tjitrosomo SS, Angka SL. Jakarta (ID): Indonesia Pr.

Rahayu P, Nurosiyah S. 2008. Evaluasi Sensori. Jakarta (ID): Universitas Terbuka.

Rahayu WP, Nurwitri CC. 2012. Mikrobiologi Pangan. Bogor (ID): IPB Pr. Rostinawati T. 2009. Aktivitas antibakteri ekstrak etanol bunga rosella (Hibiscus sabdariffa L) terhadap Escherichia coli, Salmonella typhi dan Staphylococcus aureus dengan metode difusi agar. [skripsi]. Jatinangor (ID): Universitas Padjajaran.

Ruas M, Tuinier PR, Kanning M, Zoon P. 2002. Role of exopolysaccharides produce by Lactococcus lacits subsp. Cremoris on the viscosity of fermented milk. Jurnal International Dairy. 12:689-695.

Sihombing DE. 2013. Karakterristik kimia dan mikrobiologi yoghurt probiotik susu kambing dengan penambahan ekstrak bunga rosella (Hibiscus sabdariffa L). [skripsi]. Bogor (ID): Institut Pertanian Bogor.

Steel RGD, Torrie JH. 1995. Prinsip dan Prosedur Statistik. Edisi ke-2. Terjemahan B. Sumantri. Jakarta (ID): PT. Gramedia.

Surono IS. 2004. Probiotik Susu Fermentasi dan Kesehatan. Jakarta (ID): Tri Cipta Karya.

Susanto T, Yuwono S. 2001. Pengujian Fisik Pangan. Surabaya (ID): Unesa Pr. Syarif R, Halid D. 1993. Teknologi Penyimpanan Pangan. Jakarta (ID): Arcan. 
Tamime AY, Robinson RK. 2007. Yoghurt : Science and Technology. 3nd ed. Cambridge (GB): Woodhead Publishing.

Tsai PJ, Melntosh J, Pearce P, Camden B, Jordan BR. 2002. Anthocyanin and antioxidant capacity in roselle (Hibiscus sabdariffa L) extract. Food Research International. 35:351-356.

Winarno FG, Fernandez EI. 2007. Susu dan Produk Fermentasinya. Jakarta (ID): MBRIO Pr.

Winarno FG, Fardiaz S, Fardiaz D.1980. Pengantar Teknologi Pangan. Jakarta (ID): PT. Gramedia. 